\title{
ORGANISATIONAL CULTURE AS A TOOL FOR MANAGING A MULTIGENERATIONAL WORKFORCE IN PROJECT MANAGEMENT
}

\author{
DOI: 10.17261/Pressacademia.2019.1120 \\ RJBM-V.6-ISS.3-2019(5)-p.185-203
}

\section{Selcuk Ozaydin}

MEF University, Department of Economics, Istanbul, Turkey. ozaydins@mef.edu.tr, ORCID: 0000-0003-3935-8790

Date Received: August 17, 2019

Date Accepted: September 23, 2019

To cite this document

Ozaydin, S., (2019). Organisational culture as a tool for managing a multigenerational workforce in project management. Research Journal of Business and Management (RJBM), V.6(3), p.185-203

Permanent link to this document: http://doi.org/10.17261/Pressacademia.2019.1120

Copyright: Published by PressAcademia and limited licenced re-use rights only

\begin{abstract}
Purpose - This study proposes a best practice organisational culture for managing the multigenerational workforce in project management. Organisational culture is an important tool for managing employees therefore it is quite useful for managing generational differences

Methodology - The relevant literature about organisational culture, its effects on project management and $X \& Y$ generations, are compared and contrasted.

Findings- Five aspects of organisational culture: Result Orientation, Decentralized Decision Making and Low Levels of Hierarchy \& Bureaucracy, Encouraging Innovation \& Autonomy and Not Having Standardized Procedures, Learning Environment and High Level of Integration and Communication within the Organisation are identified as decisive for managing a multigenerational workforce.

Conclusion- Generational differences are an area of concern with the increasing participation of $Y$ generation into the workforce. Employee commitment and satisfaction are highly influential on productivity therefore they should be handled with care. Organisational culture can be used as a tool for generating an ideal workplace for a multigenerational workforce.
\end{abstract}

Keywords: Project management, organisational culture, multigenerational workforce, generation $\mathrm{X}$, generation $\mathrm{Y}$ JEL Codes: M10, M12, M14

\section{INTRODUCTION}

People have different expectations from their lives, from their careers and from their jobs. Some expect power, some expect money, some expect autonomy and for achieving what they desire they go through different ways. The different expectations are shaped by one's conception of the world which is a result of his/her character. Being born in different generations and growing in different environments are influential on character development (Scar \& McCartney, 1983). The characteristic differences between generations affect their expectations and priorities.

Employees from different generations are working together in organisations and soon the younger generations will be the majority. The aging part of the workforce is highly active in senior level management positions compared to the younger generations. When older generations face the challenge of managing younger generations, conflicts occur. Organisational culture is essential in comprehending the employee behaviours, desires and interactions (Alvesson, 2002). Organisational culture can roughly be defined as the normal way or style of doing things in an organisation which is encouraged by the more experienced workers (Kotter \& Heskett, 1992). This is why the organisational culture can be a setback or a challenge for the newcomers, especially if there are generational differences between the experienced workers and newly recruited. 
Organisational culture could be a useful tool in managing the differences between generations however, how the different generations would fit into the conventional organisational cultures is a matter of question. Organisations like Google and many others try to address the methods and expectations of younger generations by building more flexible organisational cultures. In a project management perspective, he importance of organisational culture is critical for achieving successful project delivery (Suda, 2006).

The majority of the current workforce are the $X$ (born between the years 1965-1980) and $Y$ (born between the years 1981-2000) generations (UNJSPF, n.d.). When talking about today's multigenerational workforce the two main actors are these two generations.

The older generations such as the Baby Boomers (1946-1964) or the Traditionalists (1925-1945), have been participating in the workforce for decades which make them easier to be managed compared to the newer generations. Numerous studies have been done analysing the differences between generations in terms of their expectations and preferences (Myers \& Sundram, 2012; Schoch, 2012) however the there are no studies in a project management framework.

The main motivation behind conducting this research is to discover the influence of generational differences on project management and propose a best practice in terms of organisational culture to deal with the multigenerational workforce. To narrow the scope on different generations, the $X$ and $Y$ Generations are chosen since they consist the majority in the current workforce all around the world. Each generation has its own qualities, strengths and weaknesses. Identifying these characteristics would enable the managers to minimize the conflicts and maximize the efficiency in multi-generational teams especially in project management where teams have great importance on project delivery.

Following this introduction, this paper proceeds as follows. The next section provides the methodology and the literature regarding organisational culture. Section 3 introduces fundamental project management tools and techniques and Section 4 presents the findings and the discussion. Finally, Section 5 concludes this study.

\section{RESEARCH METHODOLOGY AND LITERATURE}

The relationship between generational differences and project management is an area which has not been studied before so the two subjects has to be investigated separately for establishing links. The investigation is done through reviewing the existing literature. The literature review provides the required information for being able to comprehend the subjects subject to discussion. The findings from the current literature, about $X$ and $Y$ generations and managing a multigenerational workforce, are reviewed so that the preferences and expectations of each generation can later be addressed by the appropriate aspects of organisational culture.

Three main types of literature review are widely recognized, which are: Narrative Review of the Literature, Systematic Review of the Literature and Meta-Analytic Review of the Literature (Cronin, et al., 2008).

In this study, a systematic literature review is conducted. The fundamental theories are reviewed about organisational culture such as Schein's layered model for organisational culture, Handy's typology of cultures or Burns \& Stalker's classification of organisations in terms of their openness to change and flexibility. For being able to understand the organisational culture and its influence on project management, comprehending the fundamental theories is essential.

\subsection{Systematic Review of the Literature}

Systematic reviews have a well-defined scope of literature and mostly used for reaching conclusions about objectives which have a narrower focus. A system is built for selecting literature such as studying a subject by chronologically reviewing the studies written about the subject. The reviewer investigates the development of theories through history by paying attention to the dates of the articles and books which were written about the chosen topic. The systematic reviews aim to provide the reader with a list of all studies done in the regarding matter both published and unpublished. (Cronin, et al., 2008)

The literature review is conducted to meet the following five objectives,

1. Determine the unique characteristics of $X$ and $Y$ Generations by investigating the influential factors on their development.

2. Clarify the effects of organisational culture on project management.

3. Analyse how organisational culture can address the different needs and expectations of different generations. 
4. Investigate the usability of organisational culture for managing the multigenerational workforce.

5. Determine the appropriate aspects of organisational culture for formulating a best practice organisational culture for managing a multi-generational workforce in project management.

Objective 1 requires to investigate the multigenerational workforce and to identify the characteristic traits of $X$ and $Y$ generations. Theories on organisational culture and its effects on project delivery are analysed so that Objective 2 can be achieved. The first two objectives supply the background knowledge which is needed for being able to move on to Objectives 3,4 and 5 which are the main motives behind this study.

\subsection{X \& Y Generations and the Multi-Generational Workforce}

Generation can be defined as an age group born into the same environment and go through the similar experiences and teachings in the first 20-23 years of their lives which shape their understanding of the world, values, beliefs and expectations (Underwood, 2007).

The generational classifications are made according to birth dates however there are some differences from definition to definition. In this study, UNJSPF's (United Nations Joint Staff Pension Fund) birth periods were used due to its reliability.

The influence of environment on children development have been studied numerous times and as underlined by A. Rigolon and M. Alloway (2011), the environment and the people interacting with the child affect its development. Another influential factor in child development is, the guardians' style of parenting. Parent-child relationship affects the child's development in terms of information processing and perceptual skills which would eventually result in different values, beliefs or ways of doing things (Bernier, Carlson \& Whipple, 2010).

Generations share life experiences such as the popular culture, the economic recessions, political events, natural disasters or technological advancements. Being born into different environments affects a child's development in two different ways; first, changes in daily lives due to the technological advancements such as playing computer games instead of reading books and second, difference between the parents of different generations and the inevitable difference between their parents' style of parenting.

Figure 1: Generational Time Line and Characteristic Traits

\begin{tabular}{|c|c|c|c|}
\hline $\begin{array}{l}\text { Tradnionalist } \\
\text { Born } 1825 \text { - } 1845\end{array}$ & $\begin{array}{l}\text { Baby Boomers } \\
\text { Born 18de-18a4 }\end{array}$ & $\begin{array}{l}\text { Genx: } \\
\text { Bom 18as-1880 }\end{array}$ & $\begin{array}{l}\text { GemY } \\
\text { Born } 1881 \text { and anter }\end{array}$ \\
\hline 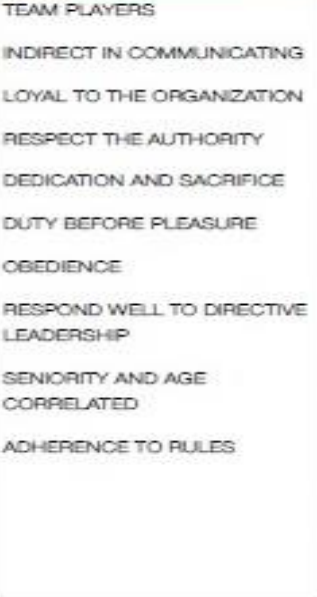 & 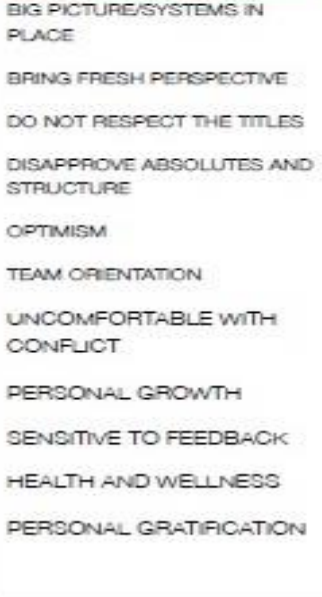 & 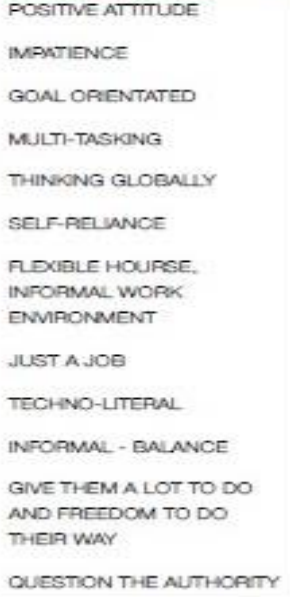 & 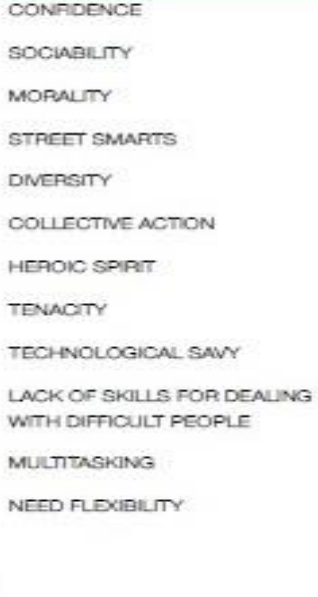 \\
\hline
\end{tabular}


The United Nations Joint Staff Pension Fund (UNJSPF) released a study (n.d.) about the generations and their typical characteristic traits. Figure 1 presents the 4 different generations which existed in the last century in a timeline as well as summarizing their characteristic traits.

As O'Bannon (2001) points out different generations need to be managed differently since the failure of the recognition of the differences between generations would cause misunderstandings and lack of communication and it would create an unpleasant working environment.

\subsection{Generation $X$}

The record divorce rates, parents sacrificing their lives for work and the coloured TV are the key elements influenced the Generation X'ers which caused them to be sceptic and self-sufficient (Faber, 2001). Most of the X'ers grew up alone watching TV since their parents were either divorced or working long hours. They have contradictory values in matters of personal life and work such as avoiding marriage because of the fear of divorce or having the fear of getting fired while looking for a better job (Faber, 2001).

Generation X'ers, prefer developing a skill set consisting of different skills rather than excelling on one subject. They believe that job-security can only be achieved by constantly updating their skill set. Their main goals are just being self-sufficient and providing a good-life for their families which is something they did not have while growing up. $X^{\prime}$ ers are just trying to find the balance between work and home so that they can look after their own interests (Fogg, 2009).

It is also important to mention that the Generation $X$ has witnessed some of the milestones in the history such as the fall of the Soviet Union or the demolition of the Berlin Wall, these incidents have influence on their sceptic and resentful character (Faber, 2001). They have seen that the world is constantly changing and there is no point in dedicating one's life into an organisation or an ideology. Generation X'ers don't believe in status because they have witnessed numerous times that authorities fall. This is why they need to be led and directed by credibility and know how rather than position and status.

It's quite common to see an X'er to start working alone instead of waiting for his/her team members to take a collective action (Patterson, 2007) which makes them bad team players. It should be kept in mind that $X^{\prime}$ ers work for financial gains, if they are not provided they'll seek the rewards somewhere else (Martin \& Tulgan, 2006). Generation X'ers are result oriented which means that sometimes choose unorthodox methods in order to get things done (Eisner, 2005). The X'ers are productive but they prefer to work smarter instead of harder so they come up with new methods of doing things which is a result of their entrepreneurial spirit.

The typical characteristic traits for the Generation X can be summarized as follows:

- Self-sufficiency and self-orientation which make them bad team players (Faber, 2001; Patterson, 2007; UNJSPF, n.d.).

- Sceptic and resentful, they are hard to convince and they have difficulty trusting others (Dennis \& Owen, 1997; Faber, 2001).

- Value skill and know how over status and position. (UNJSPF, n.d.)

- Try to set up a balance between home and work (Fogg, 2009; UNJSPF, n.d.).

- Main focus on their family and children (Bennett, et al., 1997; Fogg, 2009; Schoch, 2012; UNJSPF, n.d.).

- Motivated by pay checks rather than accomplishments and contribution to the organisation (Bennett, et al., 1997; Martin \& Tulgan, 2006; Schoch, 2012).

- Lack of loyalty, commitment and idealism (Dennis \& Owen, 1997; Eisner, 2005; Faber, 2001).

- Prefer having a skill set of different attributes rather than exceling in one (Eisner, 2005; UNJSPF, n.d.).

- Result oriented (Eisner, 2005; Patterson, 2007; UNJSPF, n.d.).

- Technologically literate (Fogg, 2009; UNJSPF, n.d.).

\subsection{Generation $Y$}

Growing up with caring parents, made the Y'ers to value their homes. Typically, Generation Y'ers got praises for every accomplishment therefore they are seeking constant feedback and attention (Raman, et al., 2011). In addition to their needy nature, the freedom of expressing themselves they had while growing up turned them into occasionally over-confident individuals who value autonomy a lot (UNJSPF, n.d.) 
Computers and internet provide an environment where the users can participate, unlike TV, so they turn into actual users not just viewers or followers. Computers enable children to start accomplishing things even in the age of five or six. Y'ers are born into a world where they can start achieving things at an early age (Tapscott, 1998).

The increasing awareness of environmental problems, inequalities, discrimination etc. affected Y'ers while growing up. They've become idealistic with strong moral and ethical values. Many Y'ers participate in social campaigns or NGOs for being a part of a bigger cause.

For the first time in history, the Generation $\mathrm{Y}$ has accomplished something which is to create an upside down knowledge hierarchy as defined by Tapscott (1998). The children of today, have more knowledge than their parents about digital tools, computers and internet which affects the family dynamics and child development. Parents started learning from their children therefore started respecting them which changed the orthodox child-parent relation. The changing household hierarchy caused the children to ask for more at school or at work in terms of respect.

Y'ers value self-development and they are constantly looking for learning opportunities. If they feel like there's nothing left to learn in the organisation they'll start looking for another place where they can learn some more. Their sense of security is to feel like they can find another job somewhere else so for making sure that they can they try to get knowledge and experience from wherever they go (Martin \& Tulgan, 2006). Generation Y dislikes formality, bureaucracy and hierarchical structures, they enjoy rapid progress and due to the fact that they can multifunction they prefer challenging tasks which push their limits (Eisner, 2005).

Generation $Y$ have integrated technology into their problem-solving techniques so, often they approach problems with different methods compared to other generations (Fogg, 2009). Social networks are an important part of life for the Generation Y'ers, they communicate and build up professional or personal relationships using social networks so this enables them to integrate their personal and professional lives together (Nikravan, 2011; Underwood, 2007; UNJSPF, n.d.).

The typical characteristic traits of the Generation $Y$ can be summarized as follows:

- Value autonomy and freedom so they can be creative and perform efficiently. (Eisner, 2005; Fogg, 2009; UNJSPF, n.d.)

- Idealistic and have high moral values. (Martin \& Tulgan, 2006; Schoch, 2012; Tapscott, 1998; UNJSPF, n.d.)

- $\quad$ Need for constant feedback and appreciation. (Raman, et al., 2011; Tapscott, 1998)

- Need for instant rewards and they often get impatient. (Fogg, 2009; Martin \& Tulgan, 2006, Schoch, 2012)

- Born into technology and natural users of it. (Fogg, 2009; Schoch, 2012; Tapscott, 1998)

- $\quad$ No distinction between personal life and career but it is important that they can socialize at work. (Nikravan, 2011; Underwood, 2007; UNJSPF, n.d.)

- $\quad$ Good at taking collective action and teamwork. (UNJSPF, n.d.; Underwood, 2007)

- $\quad$ Able to multitask and motivated by challenging tasks. (Eisner, 2005; Martin \& Tulgan, 2006)

- $\quad$ Like to be recognized as individuals and they dislike hierarchy. (Eisner, 2005; Tapscott, 1998; UNJSPF, n.d.)

\subsection{Digital Immigrants and Digital Natives}

Marc Prensky (2001) came up with the typology of digital natives and digital immigrants while studying the differences between the learning behaviours of students of the past and present. He suggested that, the students of the present are born into digital technology and their learning behaviours differentiate from the students of the past. Students of the present are the digital natives, their learning experience started as they watched TV and played video games which inevitably resulted with different perception of knowledge and different habits of learning compared to the students of the past. Today's teachers are digital immigrants who are trying to adapt to the new technology and what it has brought to the daily life. For the case of $X$ and $Y$ Generations, most of the X'ers are digital immigrants whereas the Y'ers are digital natives.

Having a workforce of different generations makes it challenging to manage however it also means having a broader skill set since the different generations have unique abilities to offer. Even though the multigenerational workforce needs managing it is also an opportunity.

\subsection{Organisational Culture and Human Capital}

Human capital is one of the most important assets of an organisation since it can create competitive advantage for an organisation (Campbell et al., 2012). If an organisation fails to provide a workplace which can addresses the different needs and expectations 
of its employees, it cannot use its human capital efficiently. Also creating a sense of harmony and commitment is extremely important for the employee performance since there is a negative correlation between the amount of conflict and stress and the performance of project management professionals (Gray, 2001). Communication, integration and commitment are all essential elements of organisational culture which are also key in managing human capital (Smith, 1997).

\subsection{Organisational Culture}

Organisational culture has become a critical issue especially in the recent past. Corporations have started paying attention on building an effective organisational culture since companies with strong organisational cultures have made more returns on investment and gains (Deal \& Kennedy, 2001). Organisational culture also affects the level of commitment of the employees to the organisation as displayed by Moon (2000) which yields returns in terms of productivity and efficiency.

Senge's (2006) theory of shared vision claims that when employees start sharing the same ideas, thoughts and emotions about the organisation, it means that they are committed and when the employees are committed they are more productive. It is important that the culture is adopted by everyone and employees are fully committed to the culture so that the organisation is able to act as a whole instead of just being a group of people working together.

Before going further in detail, it would be beneficial to define organisational culture however it is not as simple as it sounds. There are different definitions of organisational culture, for example Hofstede \& Hofstede (2005) define organisational culture as "the collective programming of the mind that distinguishes the members of one organisation from another" whereas Deal \& Kennedy (2001) define organisational culture as "the glue holding that holds an organisation together". Buchanan \& Huczynski's (2010) definition is a bit more complex, they claim that the organisational culture is "the shared values, beliefs and norms which influence the way employees think, feel and act towards others inside and outside the organisations". Organisational culture is the unique way of doing things which differs from organisation to organisation.

\subsection{Models of Organisational Culture}

\section{Schein's Model}

Edgar Schein's (2010) model of organisation culture is beneficial for being able to determine to what extent the organisational culture can be influenced by internal and external factors. It categorizes culture into three layers based on its visibility and accessibility.

Three Layers of Culture

1. Artefacts

- Visible and feelable structures and processes

- Observed behaviour

- Difficult to decipher

2. Espoused Beliefs and Values

- Ideologies

- Rationalizations

- May or may not be congruent with behaviour and other artefacts

3. Basic Underlying Assumptions

- Unconscious, taken-for-granted beliefs and values

- Determine behaviour, perception, thought and feeling

From one to three, the layers of culture get deeper, harder to see and more embedded in the organisation. The first level is the Artefacts in an organisation, these are things which are easier to see such as how people dresses, how people talk to each other or the firm's products. Artefacts are very easy to change, such as free-Fridays or putting small plants on every employee's table. Although it is easy to the notice artefacts it is difficult to interpret them. For being able to do that, one most go deeper into the organisation in order to interpret what these artefacts really mean (Schein, 2010).

The second layer is the Espoused Beliefs and Values in an organisation. These are assumptions that are accepted as truth within the organisations such as the strategy or the goals of the organisation. There might be need for the validation of these assumptions 
from time to time. Some of these values and beliefs, which are validated by the employees and managers, even might be socially unacceptable behaviours such as sexist discrimination (Schein, 2010).

Last layer is the Basic Underlying Assumptions beneath the first and second levels. These are hypothesis which have been validated numerous times and turned into reality slowly gradually over time and became unconscious behaviour. The basic underlying assumptions are non-debatable and they cannot be challenged, this is why they are extremely difficult to change and whoever denies the basic assumptions in the organisations face the threat of being dismissed or ex-communicated (Schein, 2010).

\section{Kotter \& Heskett's Model}

Kotter and Heskett (1992) also claims that culture has layers: the first layer, which is shallow and easier to understand and change and the second layer, which is deeper and harder to analyse and change.

Another key characteristic of an organisation culture is its adaptability. Kotter and Heskett (1992) argue that adaptive cultures focus on the interests of the stakeholders such as customers, suppliers, employees and this is why they are able to react to externalities. On the other hand, inadaptive cultures are narrow sighted and the main focus is the current circumstances, managers try to avoid risk as much as they can and the level of bureaucracy is high which decreases the organisations flexibility and ability to react to changes.

\section{Handy's Typology}

Handy (1993) examines the organisational culture in four main groups where structural differences are easily visible as well.

\section{Types of Culture}

1. The Power Culture

2. The Role Culture

3. The Task Culture

4. ThePersonCulture

Figure 2: Power Culture

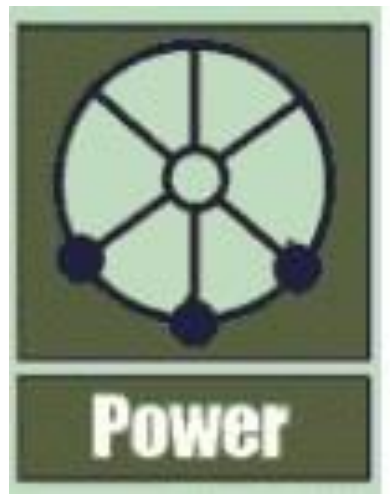

The power culture shows resemblance to a spider's web, there is a strong central power either a person or a group who has unlimited authority. There is low level of bureaucracy and personal conversions are the most important tool of communication, furthermore due to the low level of formality these organisations are flexible. The success of the organisation depends on the person or the group who is in charge. As the web gets bigger the spider's ability to monitor and control decreases this is why this culture is common in start-up businesses or small entrepreneurial firms. Individuals who work in power structures will be satisfied in terms of the power and freedom they have since the organisation is goal oriented rather than mean (Handy, 1993). 
Figure 3: Role Culture

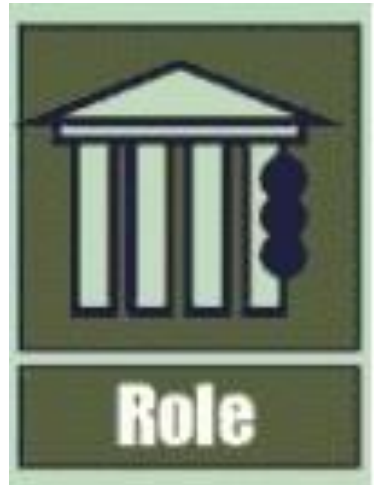

The role culture has a hierarchical structure and there is a lot of bureaucracy in it, there are defined roles and clear descriptions of who needs to do what. Expertise is valued more than creativity. The main focus for the organisation is stability and survival not growth on the other hand status is important and all the processes are formally done which creates a slow decision-making process. Individuals working in role cultures will be offered predictability and security with a previously set career ladder to climb as long as the individual sticks to the methods of the firm (Handy, 1993).

\section{Figure 4: Task Culture}

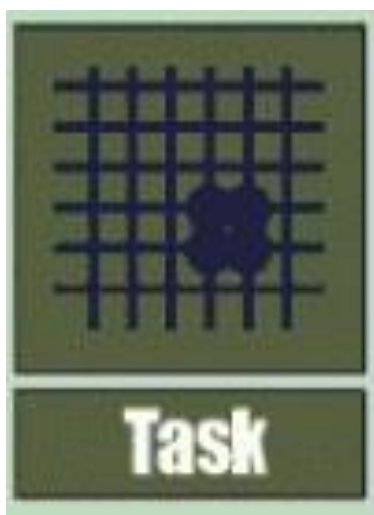

Task culture shows resemblance to a net in the sense that the power and influence lies at the intersection points of the strings. Even though some strings are thicker and stronger than the others it is not possible to talk about a strong central authority. The flexible structure task culture provides, is very suitable for project management due to the autonomy it provides. The groups consist of individuals with different skills and creative power however expertise is not present. (Handy, 1993) 


\section{Figure 5: Person Culture}

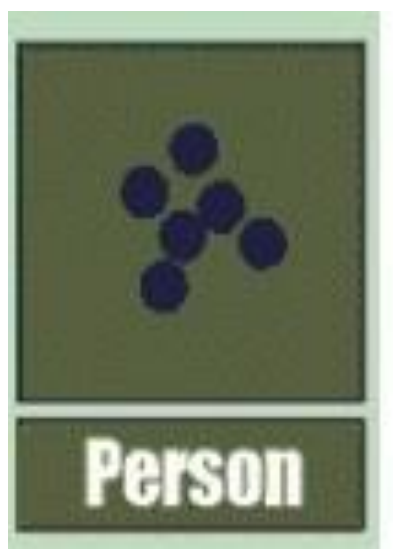

In person culture, it is very hard to talk about any kind of structure or organisational objectives. This culture serves the individual desires and objectives so there is no hierarchic decision-making mechanism or status influence, the only way to decide is mutual consent. Person culture is very hard to find among organisations however occasionally individuals act accordingly. Such as a professor in a university where he/she just teaches to fit into the organisation and work on his/her own interests or focuses on his/her career rather than feeling as a piece of the organisation or contributing to it. (Handy, 1993)

Like people organisations have different way of doing things, some develop over time through the actions of individuals or groups within the organisation and some are structurally shaped. It is not possible to isolate structure from the picture while talking about organisational culture therefore it is important to mention Burns \& Stalker's (1961) structural classification before moving on.

\section{Burns \& Stalker's Classification}

Burns and Stalker (1961) classify organisations in to two, as mechanistic and organic. According to their definition, mechanistic organisations have: high level of bureaucracy, clear and standardized definitions of methods, hierarchical structure of control, low level of autonomy and high respect for status and experience whereas organic organisations have: personalized methods and individual tasks, exchange of thoughts and consultancy rather than instructions, lower level of bureaucracy and more autonomy.

\section{Comparing Models}

The correspondence between Burns and Stalker's classification of organisations and Handy's (1993) typology of organisation culture is not surprising, as mentioned before it is not possible to talk about organisational culture or structure without mentioning the other.

The role culture mentioned earlier, shows resemblance to the mechanistic structure in the sense that there is hierarchy and bureaucracy in both. Also, experience and status are valued more than creativity and innovation. On the other hand, task culture is quite similar to the organic structure since there is high level of autonomy. Employees have more freedom, there is no predetermined method for most of the duties so the individuals are able to take initiative as long as they complete the task because the orientation is goals not the methods. Cultural elements are present in structural frames and structural elements are an important part of cultural classifications. As Kotter and Heskett (1992) state: sometimes the organisational structure requires some behaviour which are already "basic underlying assumptions" in Schein's (2010) words. Quite often strategies fail because of their incompatibility with the organisation's culture.

Porter (2004) argues that, whatever the organisational structure or the culture is, organisations must establish horizontal mechanisms for management for enhancing the organisation's ability to function. These horizontal mechanisms will have their own decision-making mechanisms, own practices and own communication schemes. He claims that, the horizontal mechanisms will increase the organisation's flexibility and its ability to change regardless of its structure and culture. 
The essence of generating a successful corporate culture is to integrate employees over a "shared vision" in Senge's (2006) words. Even individuals from the same generations experience conflicts so when the generational differences are considered it is sensible to expect more disorder. Organisational culture can affect an organisation's performance in numerous ways as demonstrated.

\section{PROJECT MANAGEMENT}

Gilbert (1983) defines a project as an organisational set up to deliver a task within previously set constraints in terms of time, cost and quality. Managing projects cannot be separated from managing the organisation as a whole even though delivering projects requires a different set of expertise (Roberts, 2013). Reiss's (2007) definition of a project highlights the importance of human factor in project management. He defines a project as a "human activity that achieves a clear objective against a time scale" and furthermore he mentions that one of the common characteristics of projects is that they all have a team of people.

For delivering successful projects, it is important to implement the appropriate tools and techniques. These tools and techniques can be named as the best practices of project management which contributes to projects and their chance of success (Loo, 2002). Like many others, Besner and Hobbs (2006) investigated the best practice tools in project management for delivering successful projects and have identified the following seven tools:

Tools of Best Practice in Project Management
1. Lessons learned/post-mortems
2. Requirements analysis
3. Scope statement
4. Work breakdown structure (WBS)
5. Project management software for monitoring of schedule
6. Project management software for task scheduling
7. Project management software for resource scheduling.

The tools of best practice are reviewed in three sub groups; tools related to the organisational learning, tools related to the planning and the software tools.

\subsection{Tools of Organisational Learning}

As projects progress, circumstances, resources and people change which creates a need for flexibility. For being able to address these changes there is a constant need for improvement in knowledge and skills which can only be achieved by creating a sustainable learning environment in the organisation (Koskinen, 2012).

\subsection{Tools of Project Planning}

As mentioned earlier, planning is the most important stage of a project which starts with analysing the requirements of the project. The organisation must make sure that it has the required resources to deliver the project as well as to set the project's scope clearly (Besner \& Hobbs, 2006). Work breakdown structure (WBS) is a tool which is used to divide the project in to smaller tasks which all create deliverables in the end and using a WBS enable the project planners to schedule the project and the required resources (Norman, 2011). 
Figure 6: A WBS Sample

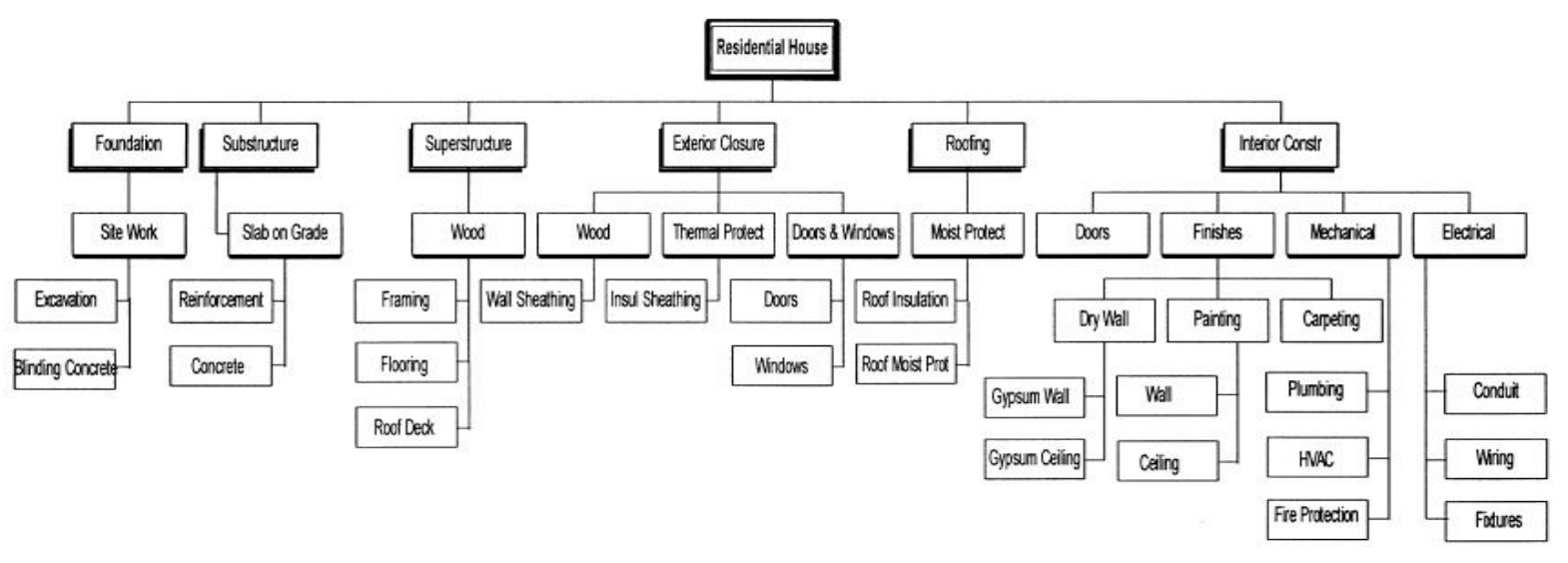

\subsection{Tools of Project Management Software}

Technology is widely used in project management through software which are used for monitoring and scheduling. Software, enable the users to enter information into the computer so that progress can be tracked and information can be shared swiftly. Such systems provide, increased project efficiency and improved decision-making capability due to the enhanced communication ability which result in increased overall project success (Deng, et al., 2001).

Project management tools and techniques are essential in delivering successful projects however they are not sufficient by themselves. Human is the key factor in project success therefore organisational culture is crucial to project management.

\subsection{Effects of Organisational Culture on Project Management}

There is a strong connection between an organisation's project success and it's because managing projects require collective action, being able to react instantly, high level of integration, flexibility (Gray \& Larson, 2011; Kerzner, 2000). Some aspects of organisational culture enhance the organisation's ability to deliver projects (Ford \& Randolph, 1992; Gray, 2001; Kerzner, 2000).

Standardizing project procedures is beneficial for project success (Rada \& Craparo, 2000) however as pointed out by Tatikonda and Rosenthal (2000) there is often need for coming up with alternative ways of problem solving instead of using the formal methods. These, will enhance the organisation's adaptability and by doing so the balance between flexibility and firmness would be achieved.

Gray and Larson (2011) state that, a project friendly organisational culture will encourage cross-departmental cooperation and integration while creating harmony and commitment within the organisation. Even though it is possible to talk about a best practice for project management, the good project management needs to be customized according to needs. Result orientation and being proactive have great importance (Kerzner, 2000) and therefore an organisational culture which is goal oriented increases the project management ability.

Making decisions while managing projects is not easy for several reasons such as the scarcity of resources or the presence of multiple stakeholders, both external and internal, (Lock, 2013) and furthermore, often project managers are obliged to take hasty decisions. Having a strong hierarchical structure would slow down the process therefore an organisation should be comfortable with a more decentralized decision-making scheme (Morrison, et al., 2006). A culture which is more decentralized, less hierarchical and less bureaucratic would increase the level of autonomy of the employees and as advocated by Young (2013) the high level of autonomy and freedom of action of the employees will have a positive impact on achieving success on projects. Tatikonda and Rosenthal (2000) point out, sometimes developing new methods is needed as well which can be only possible by providing autonomy and creating a learning environment.

Communication is another important aspect of project management and there is a close link between the efficiency of communication and project success (Tushman \& Katz, 1980). There is a need for fast and free flow of information for being able 
keep up with the rapidly changing project environment. It is important that the organisation has a culture of open communication where people can express opinions without hesitation and in mutual trust.

Project management supporting organisational cultural elements which were discussed are summarized below:

Elements of Organisational Culture for Increasing Project Success

1. High willingness to change and develop new methods, open to innovation, adaptive and flexible.

2. High level of integration and cooperation between departments.

3. Goal orientation.

4. High level of autonomy and encouraging risk taking.

5. Decentralized decision-making procedures, low level of hierarchy and low level of bureaucracy.

6. Outward orientation and market focus.

7. Promoting learning and training.

8. Eased flow of communication and mutual trust among the organisation.

Previous studies provide information about the differences between generations in terms of their expectations and priorities but also about their different approaches towards solving problems. Organisational culture's influence on human capital can be used as a tool for addressing these differences.

Even though studies have been made to uncover the effects of organisational culture on generational differences, the project management literature lacks well established links between them. This chapter summarized the relevant literature to create the knowledge base required for being able to discuss this connection.

\section{DISCUSSIONS \& FINDINGS}

Organisations seek ways to increase their efficiency or productivity and one of the ways of doing it, is creating a workplace which would increase employees' commitment, satisfaction and happiness by addressing their needs and wants (Goffee \& Jones, 2013). The information provided in the previous section is used for discussing the points where they would be able to work in harmony and the points where they might experience conflicts in terms of organisational culture. It is possible to say that there are correspondences between the generational traits and some aspects of the project management delivery enhancing organisational culture.

\section{1. $X$ and $Y$ Generations Together in the Workforce}

The differences between $X^{\prime}$ ers and Y'ers in terms of their values, beliefs and expectations are easily observable. Hicks and Hicks (1999) advocate that there are three key elements of overcoming differences between generations which are: understanding, acceptance and forgiveness. Understanding the generations is essential for being able to get the most out of the multigenerational workforce and by contrasting the unique traits of each generation, an organisational culture which is suitable for both generations can be established.

\subsection{Perception of Matters and Technology}

One of the main differences between $X^{\prime}$ ers and $Y^{\prime}$ ers is their point of view about the world. $X^{\prime}$ ers are generally more sceptic and have difficulty trusting people, they are used to doing things on their own, whereas Y'ers are usually more sociable, high spirited, positive and better team players.

Creating a balance between home and work is in general very important for $X^{\prime}$ ers, they highly value their family and children whereas Y'ers tend to not have such a strong distinction between their professional and personal lives, they often prefer working in an environment where they can socialize and make friends.

Previous generations were introduced to technology in their adulthood but X'ers were introduced when they were still young so most of them are technologically literate and know how to benefit from it. Y'ers were born into technology and have integrated technology and related tools to their daily lives. X'ers generally use technology when they need it and it's a part of their problemsolving approaches. Y'ers use technology as much as possible since they believe the easiest and fastest way of doing something is using technology. 


\subsection{Expectations and Priorities}

\section{Working Style and Satisfaction}

The workplace is like a playground for the Y'ers, they often feel like they can make new friends, socialize, learn new things and they have fun while doing them which creates a sense of commitment to the organisation. $X$ 'ers do not value these things as much as Y'ers do, especially the sociability of the organisation. They mostly believe that professional and personal lives should be separated from each other.

Both $X^{\prime}$ ers and Y'ers value self-development and training. Providing these might develop a loyalty to the organisation which is something they often lack (Underwood, 2007). Even though they might not feel fully committed to the organisation, creating a learning environment would be attractive to them, so an organisational culture which provides a learning environment for its employees would be beneficial for managing the both generations.

Y'ers are usually more willing to work for long hours in order to get things in the right way, the methods they use are generally as important as the results they get in the end which is a result of idealistic nature but when working together with $X^{\prime}$ ers their idealistic nature might cause problems. Because X'ers value a balance between home and work, they usually don't like spending long hours in the office.

\section{Project Teams and Management Aspects}

A project team consisting of only $X^{\prime}$ ers would face some difficulties in progressing since $X^{\prime}$ ers are not very good at taking collective action, often they tend to progress on their own without taking their co-workers into consideration whereas Y'ers are in general, better in working in groups since they enjoy interacting with people. X'ers usually do not develop very good personal relations and interact with others however communication and mutual understanding is extremely important for overcoming generational differences (Goffee \& Jones, 2013; Hicks \& Hicks, 1999).

The social skills Y'ers have might be useful in terms of "breaking the ice" between the members of different generations and develop trust between them, so an organisational culture enhancing the interaction and communication between employees within the organisation would be beneficial for managing the multigenerational workforce.

Both generations would value skill and capabilities over position and experience, which is beneficial in a sense because X'ers would respect and listen to the Y'ers even though they are younger, less experienced and possibly hierarchically lower than them.

Y'ers and X'ers both value freedom and autonomy and they usually prefer to be mentored instead of managed. Y'ers generally feel that they need space to be efficient and creative. The absence of bureaucracy and hierarchy would give both generations the flexibility and freedom they need as well as saving them from unnecessary time-consuming procedures and regulations.

Different levels of technology integration create different problem-solving approaches for generation $\mathrm{X}$ and $\mathrm{Y}$. Both generations are capable of using technology so they are able to understand each other most of the time in terms of technology. Still there might be differences, so an organisational culture which does not standardize problem solving approaches and which is open to innovation and change would be suitable for managing these two generations together.

Y'ers perform more efficiently when they have clear even though they are not result oriented (Underwood, 2007). It was already said that $X^{\prime}$ ers are generally more goal focused, so both generations will perform more effectively if the organisation sets clear objectives for its employees. Even though different generations have different ways of reaching to targets it is important for both of them to be goal oriented.

\section{Organisational Culture as a Tool for Managing $X$ and $Y$ Generations}

Organisational culture is influential on how employees fit into an organisation (O'Reilly, et al., 1991) so in attempts towards finding an organisational culture best practice, to address the generational differences, is a reasonable effort.

A list, of organisational culture elements required for managing a multigenerational workforce, is provided below. The elements are showing correspondence to Handy's (1993) typology of task culture. The flexibility and adaptability provided by this type of culture would create a desired working environment for both generations. The task culture is result oriented and it provides its employees the freedom to develop their own methods as long as the tasks are completed. 
Elements of Organisational Culture for Managing the Multigenerational Workforce

1) Decentralized decision-making mechanism consisting of employees from every level to be able to take quick and sensible actions.

2) Supporting internal communication and integration between employees.

3) Low levels of hierarchy and bureaucracy.

4) Must be adaptive and flexible while providing both short-term and long-term rewards in return for achieving goals.

5) Providing freedom to come up with own techniques and methodologies to for problem solving and not having standardized procedures for every task.

6) Creating a learning environment.

7) Having clearly set targets and objectives.

The next section discusses the project management tools and techniques in a generational context for checking the usability of the tools in a multigenerational environment.

\section{$X$ \& Y Generations and the Project Management Tools \& Techniques}

Previously, the tools and techniques for achieving the project management best practice were presented in three sub headings which will now be used to discuss in a generational context.

\section{Learning Tools}

The importance of creating a learning environment was illustrated in the literature review. $X$ and $Y$ generations are both attracted by the opportunity of self-improvement, so a project environment where $\mathrm{X}$ and $\mathrm{Y}$ generations will be working together would be more successful if the organisation manages to create a learning environment by promoting life-long learning and training.

\section{Planning Tools}

Project management requires standardized project procedures even though it was discussed earlier that not having standardized procedures and having flexibility would enhance an organisation's ability to deliver projects. Due to X'ers tendency do things in their own ways, they should be closely monitored. Y'ers on the other hand work better with a sense of direction so procedures such as small work packages determined by a WBS, might increase their efficiency. Also using a WBS would also enable the Y'ers to have the achievement feeling they look for all the time since they would be completing tasks which will produce visible outcomes.

\section{Project Management Software}

Both generations are technologically literate so they will be capable of using the software and they would not struggle. The tools and techniques which are used by organisations for increasing project delivery capabilities are mostly suitable for both $X$ and $Y$ generations.

\section{Project Management in the Multigenerational Environment}

The corresponding elements of organisational culture which are project management enhancing and which are appropriate for a multigenerational workforce would provide an organisational culture to deliver to successful projects in a multigenerational workforce.

\section{Table 1: Comparing Aspects of Organisational Culture}

\section{A- Project Management Enhancing}

1) High willingness to change and develop new methods, open to innovation, adaptive and flexible.

2) High level of integration and cooperation between departments.

3) Goal orientation.

\section{B- Multigenerational Workforce Managing}

1) Need for a decentralized decision- making mechanism consisting of employees from every level.

2) Supporting internal communication and integration between employees.

3) Low levels of hierarchy and bureaucracy. 


\begin{tabular}{|l|l|}
\hline $\begin{array}{l}\text { 4) High level of autonomy and encouraging } \\
\text { risk taking. }\end{array}$ & $\begin{array}{l}\text { 4) Adaptive and flexible while providing both short } \\
\text { term and long-term rewards. }\end{array}$ \\
$\begin{array}{l}\text { 5) Decentralized decision-making } \\
\text { procedures, low level of hierarchy and low } \\
\text { level of bureaucracy. }\end{array}$ & $\begin{array}{l}\text { 5) Freedom for developing personalized techniques } \\
\text { and methodologies, no standardized procedures. }\end{array}$ \\
\hline $\begin{array}{l}\text { 6) Outward orientation and market focus. } \\
\text { 7) Promoting learning and training. }\end{array}$ & 6) Creating a learning environment. \\
\hline $\begin{array}{l}\text { 8) Eased flow of communication and mutual } \\
\text { trust within the organisation. }\end{array}$ & 7) Having clearly set targets and objectives. \\
\hline
\end{tabular}

Table 1 summarizes the previously discussed aspects of organisational culture. Column A presents the project delivery enhancing traits and Column B presents the multigenerational workforce management enhancing traits. The correspondences between the two columns are easily observable. A1 and B4 \& B5 are all about the adaptability of the organisation and its willingness or openness to implementing new methods and problem-solving approaches. An organisation which gives freedom to its employees to be innovative and which is flexible enough to adapt to changes will be an organisation delivering successful projects and meeting the expectations of the multigenerational workforce. A2 and A8 are both aligned with B2 which means that fast and reliable communication enhance an organisation's ability to deliver projects with a multigenerational workforce. For organisations with a multigenerational workforce, integration and interaction of departments and employees are key factors which shows significant similarity to what Porter (2004) suggests about having horizontal mechanisms within the organisation. A3 and B7 show resemblance to each other since both aspects require the organisation to focus on goals and clearly state them. A4 is related with B5 since in order to be able to have the freedom of personalized methods, employees need to have autonomy and willingness to take risks. A5 and B1 \& B3 are almost the same so having a decentralized decision-making system, a low level of hierarchy and a low level of bureaucracy are all enhancing an organisation's ability to deliver projects and also beneficial for managing $X$ and $Y$ generations together and enable them to perform effectively. Creating a sustainable learning environment is beneficial for delivering projects and attracting both $\mathrm{X}^{\prime}$ ers and $\mathrm{Y}^{\prime}$ ers by addressing their demands as pointed out in A7 and B6.

The presence of multigenerational workforce can have a strong effect an organisation's ability to deliver projects through the organisational culture. The probable negative effects can be mitigated or the efficiency of the multigenerational workforce can be increased to get the most out of the employees by an appropriate organisational culture.

In the next section a best practice in terms of organisational culture is suggested for managing the $X$ and $Y$ generations together in project management.

\section{Organisational Culture to Mediate the Differences}

Certain aspects of organisational culture can be used to address the needs and expectations of generations $\mathrm{X}$ and $\mathrm{Y}$. Organisational culture is influential on increasing the cooperation between employees regardless of their generations.

Numerous studies have been conducted about the relation between organisational culture and employee commitment and furthermore commitment is highly influential on employee performance. Commitment is a psychological contract between the employee and the organisation which is often much stronger than a one on paper. When the different perspectives of different generations are taken into consideration the influence of organisational culture is tremendous. Organisational culture can be used to mediate between generations.

Organisational culture is critical, especially in project management since employee productivity is an extremely important factor in project management. The generational differences cause disparity between employees and it is not possible to be productive and to perform as a whole. To be able to that organisational culture is an extremely valuable tool because it can mediate the differences between generations.

\section{An Organisational Culture Best Practice Proposal for Managing the X \& Y Generations}

A best practice is a method, technique or a way of doing something which is better at delivering the desired outcome compared to the other ways or approaches (Camp, 1989). In project management a best practice can enhance an organisation's ability to deliver successful projects. Due to its nature, project management brings employees from different departments and forms 
project groups where the key resource is the employees themselves (Clark \& Colling, 2005). The employees in project groups are not just from different departments but also from different generations.

In the previous section, the findings regarding the coincidence between aspects of organisational culture which are beneficial for managing the multigenerational workforce and which are beneficial for delivering successful projects were presented. Now, these aspects are outlined in a framework leading to an organisational culture best practice proposal.

\section{1) Result Orientation}

One of the fundamental steps of project management is setting clear objectives (Metaxiotis, et al., 2005) and as discussed earlier, organisations that are goal oriented are more successful in delivering projects. Members of the generation $\mathrm{X}$ are result oriented and generation Y'ers sometimes lose their sense of direction, so having an organisational culture which focuses on goals is extremely important for managing the multigenerational workforce in project management.

\section{2) Decentralized Decision Making and Low Levels of Hierarchy \& Bureaucracy}

An organisation should be comfortable with a decentralized decision-making mechanism since often project groups need the autonomy do make decisions. The natures of both generations are against having a positional or an experienced based decisionmaking structure where there is a central authority.

\section{3) Encouraging Innovation \& Autonomy and Not Having Standardized Procedures}

The organisations which are flexible and adaptive are more successful in project management. Also due to the differences between the problem-solving approaches of the generations, there is need for autonomy and room for creativity. In a multigenerational environment, having standardized procedures would diminish the efficiency of both generations since they won't be able to perform in line with their aspirations.

\section{4) Learning Environment}

Promoting learning and training is important for a project organisation since it allows the organisation to prepare its employees for the future. X'ers and Y'ers are both looking for opportunities where they can develop themselves. The X'ers believe in "what is in it for me" philosophy and Y'ers believe that one should be always developing him/herself for being able to be successful so creating a such environment is needed.

\section{5) High Level of Integration and Communication within the Organisation}

The need for taking collective and quick actions in project management creates a need for fast flow of information and integration among departments within the organisation. The generational barriers can be overcome by mutual understanding and to achieve that, there is need for interaction and integration between employees.

The five aspects of organisational culture which are mentioned above are the five crucial points for achieving the desired organisation culture scheme. In other words, the best practice organisational culture in project management for managing a multigenerational workforce, consisting of $X$ and $Y$ generations is made up of these five main cultural elements.

Productivity of an organisation is highly dependent on creating a workplace which would increase employees' commitment, satisfaction and happiness. Organisational culture is an important tool for generating the ideal workplace. The correspondence between the appropriate organisational culture types would be a key in managing a multigenerational workforce.

\section{CONCLUSIONS}

The interest in the generational differences has been increasing especially in the last decade after the entry of the $Y$ generation in the workforce. Organisations are trying to find ways to attract young talent as well as making the most out of the old ones. Human is the most valuable asset in project management which needs to be managed very efficiently. Generational barriers might reduce the effectiveness of the human capital in an organisation. This study aims to establish a relationship between the two phenomena which were previously subject of numerous studies independently from each other.

The main objective of this study is to develop a best practice organisational culture for managing the multigenerational workforce in a project environment. Five key elements: Result Orientation, Decentralized Decision Making and Low Levels of Hierarchy \& Bureaucracy, Encouraging Innovation \& Autonomy and Not Having Standardized Procedures, Learning Environment and High Level 
of Integration and Communication within the Organisation are identified as being required for the best practice organisational culture for managing a multigenerational workforce in project management.

Even though this study established substantial links between the two aspects of project management, the relationship between the two is still open for further development. The best practice which was suggested needs to be tested so that the pros and cons can be observed and certain improvements can be suggested. Future researchers who are interested in the link between project management and generational differences should take this study as a starting point and investigate the relationship in further detail.

This study discovers the relationship between project management and multigenerational workforce. The contribution of this research to the literature is the relationship it uncovers between project management and generational differences furthermore this study suggests a best practice in terms of organisational culture to enhance an organisation's ability to deliver projects using a multigenerational workforce.

\section{REFERENCES}

Alvesson, M. (2002). Understanding Organizational Culture. London: Sage Publications.

Bennett, S. E., Craig, S. C., \& Rademacher, E. W. (1997). Generations and Change: Some Initial Observations. In S. C. Craig, \& S. E. Bennett (Eds.), After the Boom - The Politics of Generation X (pp. 1-19). London: Rowman \& Littlefield Publishers.

Bernier, A., Carlson, S. M., \& Whipple, N. (2010). From External Regulation to Self-Regulation: Early Parenting Precursors. Child Development, 81(1), 326-339.

Besner, C., \& Hobbs, B. (2006). THE PERCEIVED VALUE AND POTENTIAL CONTRIBUTION OF PROJECT MANAGEMENT PRACTICES TO PROJECT SUCCESS. Project Management Journal, 37(3), 37-48.

Buchanan, D. A., \& Huczynski, A. A. (2010). Organizational Behaviour (7. ed.). Harlow: Pearson Education.

Burns, T., \& Stalker, G. M. (1961). The management of innovation (1. ed.). London: Tavistock Publications.

Camp, R. C. (1989). Benchmarking - The Search for Industry Best Practices that Lead to Superior Performance. Milwaukee: ASQC Quality Press.

Campbell, B. A., Coff, R., \& Kryscynski, D. (2012). RETHINKING SUSTAINED COMPETITIVE. Academy of Management Review, 37(3), 376-395.

Clark, I., \& Colling, T. (2005). The management of human resources in project management-led organizations. Personnel Review, 34(2), $178-191$.

Cronin, P., Ryan, F., \& Coughlan, M. (2008). Undertaking a literature review:a step-by-step approach. British Journal of Nursing, $17(1), 38-42$.

Deal, T. E., \& Kennedy, A. A. (2001). The New Corporate Cultures - Revitalizing the Workplace after Downsizing, Mergers and Reengineering (1. ed.). Cambridge: Perseus Publishing.

Deng, Z. M., Li, H., Tam, C. M., Shen, Q. P., \& Love, P. E. (2001). An application of the Internet-based project management system. Automation in Construction, 10(2), 239-246.

Dennis, J., \& Owen, D. (1997). The Partizanship Puzzle. In S. C. Craig, \& S. E. Bennett (Eds.), After the Boom - The Politics of Generation X (pp. 4361). London: Rowman \& Littlefield Publishers.

Eisner, S. P. (2005). Managing Generation Y. SAM Advanced Management Journal, 70(4), 4-15.

Faber, B. D. (2001). Gen/ethics? Orgizational ethics and student and instructor conflicts in workplace training. Technical Communication Quarterly, 10(3), 291-316.

Fogg, P. (2009). When Generations Collide. Education Digest, 74(6), 25-30.

Ford, R. C., \& Randolph, W. A. (1992). Cross-Functional Structures: A Review and Integration of Matrix Organization and Project Management. Journal of Management, 18(2), 267-294.

Gilbert, G. P. (1983). Styles of project management. International Journal of Project Management, 1(4), $189-193$.

Goffee, R., \& Jones, G. (2013). Creating the Best Workplace on Earth. Harvard Business Review, 91(5), 98-106.

Gray, C. F., \& Larson, E. W. (2011). Project Management - The Managerial Process (5. ed.). New York: McGraw-Hill. 
Gray, R. J. (2001). Organisational climate and project success. International Journal of Project Management, 19, $103-109$.

Handy, C. (1993). Understanding Organizations (4. ed.). London: Penguin Group.

Hicks, R., \& Hicks, K. (1999). Boomers, Xers and Other Strangers - Understanding the Generational Differences That Divide Us. Illinois: Tyndale House Publishers.

Hofstede, G., \& Hofstede, G. J. (2005). Cultures and Organizations - Software of the Mind (2. ed.). New York: McGraw-Hill.

Kerzner, H. (2000). Project Management - A Systems Approach to Planning, Scheduling and Controlling (8. ed.). New Jersey: John Wiley \& Sons Inc.

Koskinen, K. U. (2012). Organizational Learning in Project-Based Companies: A Process Thinking Approach. Project Management Journal, 43(3), 40-49.

Kotter, J. P., \& Heskett, J. L. (1992). Corporate Culture and Performance (1. ed.). New York: The Free Press.

Lock, D. (2013). Naked Project Management [E-Book]. Farnham: Ashgate Publishing.

Loo, R. (2002). Working towards best practices in project management: a Canadian study. International Journal of Project Management, 20(2), 93-98.

Martin, C. A., \& Tulgan, B. (2006). Managing the Generation Mix: From Urgency to Opportunity (2. ed.). Amherst: HRD Press.

Metaxiotis, K., I. Zafeiropoulos, K. N., \& Psarras, J. (2005). Goal directed project management methodology for the support of ERP implementation and optimal adaptation procedure. Information Management \& Computer Security, 13(1), 55-71.

Moon, M. J. (2000). Organizational Commitment Revisited In New Public Management. Public Performance \& Management Review, 24(2), 177194.

Morrison, J. M., Brown, C. J., \& Smit, E. v. (2006). A supportive organisational culture for project management in matrix organisations: A theoretical perspective. South African Journal of Business Management, 37(4), 39-54.

Myers, M. D., \& Sundaram, D. (2012). Digital Natives - Rise of the Social Networking Generation. University of Auckland Business Review, 15(1), 30-37.

Nikravan, L. (2011). The Gen Y Workplace. Chief Learning Officer, 10(10), 36-41.

Norman, E. S. (2011). Work Breakdown Structures: the Foundation for Project Management Excellence. Hoboken: John Wiley \& Sons.

O'Bannon, G. (2001). Managing Our Future: The Generation X Factor. Public Personnel Management, 30(1), 95-109.

O'Reilly, C. A., Chatman, J., \& Caldwell, D. F. (1991). People and Organizational Culture: A Profile Comparison Approach to Asessing PersonOrganization Fit. Academy of Management Journal, 34(3), 487-516.

Patterson, C. K. (2007). Generational Diversity - The Impact of Generational Diversity in the Workplace. The Diversity Factor, 15(3), 17-22.

Porter, M. E. (2004). Competitive advantage: creating and sustaining superior performance (1st Free Press Exported ed.). New York: Free Press.

Prensky, M. (2001). Digital Natives, Digital Immigrants Part 1. On the Horizon, 9(5), 1-6.

Rada, R., \& Craparo, J. (2000). Standardizing Software Projects. Communications of the ACM, 43(12), 21-25.

Raman, G., Ramendran, C., Beleya, P., Nodeson, S., \& Arokiasamy, L. (2011). Generation Y In Institution of Higher Learning . Journal of Economics and Business Modeling, 2(2), 142-148.

Reiss, G. (2007). Project Management Demystified (3. ed.). Oxon: Taylor \& Francis.

Rigolon, A., \& Alloway, M. (2011). Children and their development as the starting point: A new way to think about the design of ele mentary schools. Educational \& Child Psychology, 28(1), 64-76.

Roberts, P. (2013). Guide to Project Management: Getting it right and achieving lasting benefit (2. ed.). London: Profile.

Scar, S., \& McCartney, K. (1983). How people make their own environments: A theory of genotype greater than environment effects. Child Development, 54, 424-453.

Schein, E. H. (2010). Organizational Culture and Leadership (4. ed.). San Fransisco: Jossey-Bass.

Schoch, T. (2012). Turning the Ship Around with a Four-Generation Crew. Information Management, 46(4), 25-29. 
Senge, P. M. (2006). The Fifth Discipline - the art and practice of the learning organization (reviewed and updated ed.). London: Random House Business.

Smith, P. J. (1997). The 8 practices of exceptional companies: How great organizations make the most of their human assets. Human Resource Management, 36(3), 367-369.

Suda, L. V. (2006). The Meaning and Importance of Culture for Project Success. Project Perspectives, 28(1), 48-52.

Tapscott, D. (1998). growing up digital - The Rise of the Net Generation. New York: McGraw-Hill.

Tatikonda, M. V., \& Rosenthal, S. R. (2000). Successful execution of product development projects: Balancing firmness and flexibility in the innovation process. Journal of Operations Management, 18, 401-425.

Tushman, M. L., \& Katz, R. (1980). EXTERNAL COMMUNICATION AND PROJECTPERFORMANCE: AN INVESTIGATION INTO THE ROLE OF GATEKEEPERS. Management Science, 26(11), 1071-1085.

Underwood, C. (2007). Bridging the Generation Gaps. American Gas, 89(6), 42-43.

Underwood, C. (2007). The Generational Imperative - Understanding Generational Differences In The Workplace, Marketplace And Living Room. North Charleston: BookSurge.

United Nations Joint Staff Pension Fund. (n.d.). Traditionalists, Baby Boomers, Generation X, Generation Y (and Generation Z) Working Together. Retrieved July 3, 2013, from

http://www.un.org/staffdevelopment/pdf/Designing\%20Recruitment,\%20Selection\%20\&\%20Talent\%20Management\%20Model\%20tailored\%2 0to\%20meet\%20UNJSPF's\%20Business\%20Development\%20Needs.pdf

Young, T. L. (2013). Successful Project Management (4. ed.). London: Kogan Page. 